\title{
Phylogeography and evolution of the triplefin Tripterygion delaisi (Pisces, Blennioidei)
}

\author{
Vera S. Domingues • Vitor C. Almada • \\ Ricardo S. Santos • Alberto Brito • \\ Giacomo Bernardi
}

Received: 15 September 2005 / Accepted: 23 March 2006 / Published online: 14 June 2006

(C) Springer-Verlag 2006

\begin{abstract}
The genus Tripterygion (Risso 1826) is restricted to the eastern Atlantic and the Mediterranean, and comprises only three species. T. melanuros and $T$. tripteronotus are essentially endemic to the Mediterranean, while Tripterygion delaisi occurs in the Atlantic and in the Mediterranean. Two subspecies of $T$. delaisi have been described ( $T$. $d$. xanthosoma in the Mediterranean and $T$. $d$. delaisi in the Atlantic). Several scenarios have been proposed for the evolution of $T$. delaisi subspecies, but so far its subspeciation process is not clear. In this study we present a population survey of $T$. delaisi including specimens from the two
\end{abstract}

Communicated by R. Cattaneo-Vietti, Genova

V.S. Domingues $(\varangle) \cdot$ V. C. Almada Instituto Superior de Psicologia Aplicada, Unidade de Investigação em Eco-Etologia, R. Jardim do Tabaco 34,

1149-041 Lisbon, Portugal

e-mail: veradomingues@ispa.pt

V. S. Domingues · R. S. Santos

Departamento de Oceanografia e Pescas,

Universidade dos Açores, 9901-862 Horta,

Azores, Portugal

V. S. Domingues · G. Bernardi

Department of Ecology and Evolutionary Biology,

University of California Santa Cruz, 100 Shaffer Road,

Santa Cruz, CA, 95060, USA

\footnotetext{
A. Brito

Departmento Biología Animal (Ciencias Marinas),

Universidad de La Laguna, Avenida Astrofísico

Francisco Sánchez s/n, 38206 La Laguna, Tenerife,

Islas Canarias, Spain
}

recognized subspecies. We combined a phylogeographic approach with estimates of the direction of migration (between the Atlantic and the Mediterranean) and of the coalescence time of the two subspecies, using polymorphic mitochondrial and nuclear genes. The results of this study clearly support the existence of two Tripterygion delaisi clades, one in the eastern Atlantic islands and another in the Atlantic coasts of Europe and in the Mediterranean. Historical migration between the islands and Western Europe plus Mediterranean was restricted, and showed a westbound trend, with a higher number of migrants going from the Western Europe plus Mediterranean into the islands. We estimated the time of coalescence of both groups of $T$. delaisi to be more recent than the onset of Pleistocene glaciations (1.7 Mya). Our results are consistent with previous hypothesis that consider successive dispersal events of a Tripterygion ancestor from the western African coast colonizing the Atlantic islands and the Mediterranean, promoting the evolutionary divergence between these areas.

\section{Introduction}

Despite the fact that the Mediterranean and adjacent Atlantic have been considered the same biogeographical province (Briggs 1974), several recent studies using molecular markers addressed levels of differentiation between these regions. Studies on different marine organisms have shown contrasting results. Some species exhibit little gene flow and strong genetic divergence between Atlantic and Mediterranean populations (Kotoulas et al. 1995; Borsa et al. 1997; Chikhi et al. 1997; Naciri et al. 1999; Aurelle et al. 
2003; Bargelloni et al. 2003, 2005), while others show very high levels of gene flow (Bargelloni et al. 2003, 2005; Costagliola et al. 2004; Duran et al. 2004; Zardoya et al. 2004). An emerging pattern is shown in cases of closely related species. In such cases one of two sister species is present in the Mediterranean and adjacent Atlantic while the other is found in tropical west Africa and Macaronesian islands (eg. Chromis chromis and C. limbata, Domingues et al. 2005; Parablennius sanguinolentus and $P$. parvicornis, Almada et al. 2005a). Thus the study of the boundary between these regions may shed light on the role of biogeographic breaks in the formation and maintenance of speciation events.

Several scenarios have been proposed for the evolution and phylogeography of the ichthyofauna of the northeastern Atlantic and the Mediterranean. Based on small cryptic fishes (blennioids), Zander (1980) described the Macaronesian islands as a center of speciation for the Atlantic blennioids from which the new species have colonized the western European shores. Almada et al. (2001) proposed the tropical coast of Africa and the Mediterranean as possible speciation centers of the northeastern Atlantic blenniids, serving also as refugia during the glacial periods.

Triplefin blennioids (family Tripterygiidae) comprise a number of small demersal fish living in rocky habitats. The genus Tripterygion (Risso 1826) is restricted to the eastern Atlantic and the Mediterranean (Zander 1986; Wirtz 1990). In recent years only three species of this genus have been recognized in the entire area. Tripterygion melanurus (Guichenot 1850), and T. tripteronotus (Risso 1810) are essentially endemic to the Mediterranean (but there are indications pointing to the existence of an Atlantic population on the coasts of northwest Morocco; Brownell 1978). T. delaisi (Cadenat and Blache 1970) is distributed in two disjunct areas: a southern area comprising western tropical Africa north to Senegal and the Macaronesian islands, and a second area comprising the Mediterranean sea and adjacent northeastern Atlantic waters south to Casablanca and Morocco, and north to the British Isles. Indeed, although Zander (1986) mentioned the species as ranging from southern England to Senegal, there are no records of triplefins between Casablanca and Senegal. Moreover a recent survey did not detect it in Western Sahara (Falcón et al. 2002). The name T. xanthosoma (Zander and Heymer 1970) was recognized for the Mediterranean, but Wirtz (1980) placed T. xanthosoma in synonymy with the eastern Atlantic T. delaisi. In spite of this, Wirtz (1980) recognized that there were small differences among populations of different locations that could be statisti- cally detected if sufficiently large samples were analyzed. Zander (1986), based on the courtship behavior and color of the males, considered that the differences between the Mediterranean and Atlantic populations of $T$. delaisi were sufficient to ascribe them to two different subspecies ( $T$. $d$. xanthosoma in the Mediterranean and T. $d$. delaisi in the Atlantic). Thus, the three species are sympatric in the Mediterranean where they differ in microhabitats preferences, both in terms of depths and level of illumination (Wirtz 1978). T. delaisi lives at a depth of 3-40 m, T. tripteronotus between 0 and $6 \mathrm{~m}$ and T. melanurus between 0 and $18 \mathrm{~m}$ (Wirtz 1978). T. delaisi prefers darker places while T. tripteronotus and T. melanurus occurs in small caves (Wirtz 1978). Interestingly, the western African populations of $T$. delaisi from Senegal do not show these habitat restrictions occupying all depth levels and light zones that were described for the three species in the Mediterranean (Wirtz 1980). All three species exhibit territorial breeding and male parental care of benthic eggs. Dispersal is restricted to their planktonic larval phase, which is very similar for the three species (17-18 days in the case of $T$. delaisi and T. tripteronotus, and 1518 days for T. melanurus; Raventós and Macpherson 2001).

The presence of a single species widely distributed in the eastern Atlantic, and in the Mediterranean and two other species ecologically very distinct in the Mediterranean, has raised the interest of many biologists to understand the biology and evolutionary history of the genus. Different hypotheses have been proposed for the speciation of Tripterygion. Zander (1973) suggested that during the last glaciations Tripterygion evolved into two different populations along the western African coast: a cold-resistant northern population and a southern population better adapted to warmer waters. After the glaciations, each of these populations might have migrated into the Mediterranean evolving there into two different species: T. xanthosoma (now $T$. delaisi) and T. tripteronotus. Wirtz $(1978,1980)$ proposed several invasions of the Mediterranean by a primary west african Trypterygion. This author suggests that the fluctuation of the sea level during the last glaciations caused the isolation of the Mediterranean from the Atlantic, promoting speciation within the Mediterranean. According to this model, the Mediterranean population of $T$. delaisi resulted from the last group of invaders. Jonge and Videler (1989) suggested that $T$. delaisi evolved into T. tripteronotus within the Mediterranean after the last glaciations, either sympatrically or in allopatry. Geertjes et al. (2001) hypothesized that the divergence between the three species started before the Pleistocene and that T. melanurus and $T$. 
tripteronotus survived the Pleistocene glaciations in refugia within the Mediterranean. According to the same authors, $T$. tripteronotus and $T$. delaisi might have diverged sympatrically in the Mediterranean. Recently, Carreras- Carbonell et al. (2005) attempted to clarify the phylogenetic relationships and taxonomic status of Tripterygion using four mitochondrial markers and one nuclear gene, which unfortunately showed a single haplotype for the three species. According to the same authors the speciation process of Tripterygion may have resulted from a rapid radiation event after the Messinian Salitiny Crisis (5.2 Mya) leading to a trichotomy. The same authors showed that the two subspecies of $T$. delaisi have originated much more recently, probably during the climatic Quaternary fluctuations (1.10 $1.23 \mathrm{Mya})$. Interestingly, they found that of the five specimens of $T$. delaisi from the Atlantic they analyzed, one, from northwestern Spain, clearly clustered with the Mediterranean samples, while the remaining four (two from Azores and two from the Canaries) formed a very distinct cluster. Thus, Carreras-Carbonell et al. (2005) stated that further sampling of $T$. delaisi in the Atlantic is necessary to assess the direction of migration between the Atlantic and the Mediterranean in order to determine the subspeciation process.

In this study we present a population survey of Tripterygion delaisi including specimens from the two recognized subspecies. Our goals were to evaluate the extent of the genetic divergence between the northeastern Atlantic islands versus the European western coast and the Mediterranean populations, and to clarify the process of subspeciation of $T$. delaisi. We analyze polymorphic mitochondrial and nuclear genes to compare populations of $T$. delaisi from the Atlantic (Azores, Madeira, Canaries, and the continental coast of Portugal) and the Mediterranean. To shed some light on the process of evolution of $T$. delaisi subspecies, a phylogeographic approach was combined with estimates of the direction of migration (between the Atlantic and the Mediterranean) and of the coalescence time of the two subspecies.

\section{Materials and methods}

\section{Sampling and DNA extraction}

Samples of Tripterygion delaisi were obtained from three eastern Atlantic islands (Azores, Madeira, and the Canaries), from the Portuguese Atlantic coast (Arrábida) and from the Mediterranean (Vivara and Capri in Italy, Croatia and Cyprus). The other two species of the genus Tripterygion, T. tripteronotus and
T. melanurus, were also included in the analysis and $T$. melanuros was used as outgroup, following the phylogenetic relationships recovered by Carreras-Carbonell et al. (2005). Samples were collected by hand nets while scuba diving. Fin clips were cut immediately after collection of the individuals and stored at ambient temperature in $95 \%$ ethanol. Tissues were digested overnight at $55^{\circ} \mathrm{C}$ in $700 \mu \mathrm{l}$ of extraction buffer $(400 \mathrm{mM}$ $\mathrm{NaCl}, 10 \mathrm{mM}$ Tris, 2mM EDTA, 1\% SDS). We purified the DNA by standard chloroform extraction and isopropanol precipitation (Sambrook et al. 1989).

DNA amplification and sequencing

Amplification of the $5^{\prime}$ hypervariable portion of the mitochondrial control region (also called D-loop) was accomplished with universal primers CR-A and CR-E (Lee et al. 1995), and used a cycling profile of $45 \mathrm{~s}$ at $94^{\circ} \mathrm{C}, 45 \mathrm{~s}$ at $52^{\circ} \mathrm{C}, 1 \mathrm{~min}$ at $72^{\circ} \mathrm{C}$, for 35 cycles. Each $13 \mu \mathrm{l}$ reaction contained 5-50 ng of DNA, $10 \mathrm{mM}$ Tris $\mathrm{HCl}(\mathrm{pH} 8.3$ ), $50 \mathrm{mM} \mathrm{KCl}, 1.5 \mathrm{mM} \mathrm{MgCl} 2,1.25 \mathrm{u}$ of Taq DNA polymerase (Perkin-Elmer, Norwalk, CT), $150 \mathrm{mM}$ of each dNTP, and $0.3 \mathrm{mM}$ of each primer. In addition, we amplified and sequenced the second intron of the $\mathrm{S} 7$ ribosomal protein gene, using the primers S7RPEX2F and S7RPEX3R (Chow and Hazama 1998), and an annealing temperature of $56^{\circ} \mathrm{C}$. After purification following the manufacturer's protocol (Applied Biosystems, Forter City, CA), direct sequencing was performed with an ABI 3100 automated sequencer (Applied Biosystems).

\section{Data analysis}

We used the computer program Clustal V implemented by Sequence Navigator (Applied Biosystems) to align the sequences. Number of haplotypes and haplotype diversity were calculated using the software package ARLEQUIN (vers. 2.000; Schneider et al. 2000). For the nuclear marker, we could not ascribe the two alleles of heterozygous positions to one of the sequences of each individual. Sample size was not enough for a maximum likelihood estimation of the allelic constitution of each sequence. Thus, we adopted a reliable criterion, using one sequence per individual scoring the variable sites with alternative nomenclature.

Phylogenetic relationships were assessed using Maximum Parsimony and Neighbor-Joining. As we were dealing with very closely related species, with small genetic distances, we adopted the $\mathrm{p}$ distance following Nei and Kumar (2000). Both methods were implemented by the software package PAUP (vers. 4.0; Swofford 1998). Topological confidence was evaluated for 
Maximum Parsimony and Neighbor-joining with 1,000 bootstrap replicates (Felsenstein 1985).

Gene flow (Fst) was estimated using ARLEQUIN (vers. 2.000; Schneider et al. 2000). Corrections for simultaneous multiple comparisons were applied using sequential Bonferroni correction (Rice 1989). Population structure was evaluated by an analysis of molecular variance (AMOVA; Excoffier et al. 1997) grouping the populations into two groups: eastern Atlantic islands versus Arrábida and Mediterranean. The AMOVA was implemented in ARLEQUIN (vers. 2.000; Schneider et al. 2000).

\section{Historical demography}

Estimates of $\Theta=2 \mathrm{~N} \mu$, where $\mu$ is the mutation rate for mitochondrial control region, were made for the two groups described above. The parameter $\Theta$ was estimated under an unconstrained exponential growth parameter. We used FLUCTUATE (Kuhner et al. 1998) to estimate the maximum likelihood of the parameters $\Theta$ and $g$ (the exponential growth parameter in units $\mu^{-1}$ ). Seeds for all analyses were generated randomly. Analyses were repeated 10 times per region to ensure stability of parameters estimates. Final analyses of each dataset employed ten short Monte Carlo chains of 200 steps each and five long chains of length 20,000, with a sample increment of 20 . The time of coalescence was estimated by assuming that coalescence was reached when the population size was reduced to $1 \%$ of its present day value, following Wares and Cunningham (2001). In order to estimate coalescence time, we used the mutation rate $(\mu)$ for mitochondrial control region as $8.24 \times 10^{-8}-9.30 \times 10^{-8}$ that was estimated using an internally calibrated molecular clock (Domingues et al. 2005). Exchanges and range expansions (immigration) between the island and Arrábida plus Mediterranean were estimated using MIGRATE 2.0 (Beerli and Felsenstein 2001; Beerli 2004). This software gives the value $M(M=m / \mu)$, which is the number of migrants scaled by the mutation rate. Again, analyses were repeated $10 \times$, to ensure stability of parameter estimates. Final analyses of each dataset employed ten short Monte Carlo chains with 5,000recorded genealogies and five long chains with 50,000 recorded genealogies, and a sample increment of 20.

\section{Results}

DNA sequences and phylogenetic analysis

Mitochondrial control region sequences were obtained from 72 individuals including 66 Tripterygion delaisi, three $T$. tripteronotus, and three T. melanurus. In addition, second intron of the S7 ribosomal protein gene sequences was obtained from 56 samples, $50 \mathrm{~T}$. delaisi, three T. tripteronotus, and three T. melanurus. Sequences of the mitochondrial control region and S7 intron were 352 and 450 bp long, respectively. Number of haplotypes and haplotype/genotypic diversities are shown in Table 1.

Both methods of phylogenetic inference resulted in a similar topology. Neighbor-joining phylogenies based on the mitochondrial control region and S7 intron sequences are presented in Figs. $2 \mathrm{a}$ and b. For both genes, $T$. delaisi were found to partition in two major sister clades, one including samples from the eastern Atlantic islands and the other including samples from mainland Portugal (Arrábida) and the Mediterranean. The two clades were defined by 16 fixed differences in the control region. For the nuclear marker S7, heterozygous individuals make the analysis of fixed differences more complex during direct sequencing. We found that seven nucleotides are uniquely found on the Atlantic islands and two nucleotides are uniquely found on the mainland and the Mediterranean, resulting in the phylogenetic separation of those two regions into two different clades as described above. These clades were well supported for the mitochondrial control region but showed lower bootstrap values for the S7 intron (less than $50 \%$ for maximum parsimony).

\section{Population structure}

Population structure was first assessed by looking at gene flow between the seven populations in our study (Table 2). As expected, gene flow estimates were higher in the nuclear marker than in the mitochondrial marker (Table 2). As described above, no gene flow was detected between the mainland/Mediterranean and the Atlantic Islands. Within these regions, markers showed a higher level of gene flow within the island group (Fst ranging from 0.085 to 0.523 for Dloop and from 0.000 to 0.053 for S7), than within the mainland Portugal and Mediterranean populations (Fst ranging from 0.260 to 0.981 for Dloop and from 0.000 to 1.000 for S7). While these numbers were mostly driven by small sample sizes in the Mainland/Mediterranean group, results still held when only considering the two largest populations (Italy and Arrábida).

The analysis of molecular variance showed a high degree of differentiation between the two groups of populations $(86.56 \%$ and $64.58 \%$ for Dloop and S7, respectively). Uncorrected $\mathrm{p}$ distances between these two groups were high (average $=0.068, \mathrm{SD}=0.009, \mathrm{~min}=$ $0.047, \max =0.083$ for Dloop; and average $=0.024$, 
Table 1 Collection localities, diversity indexes and date of collection of Tripterygion delaisi, T. tripteronotus and T. melanurus used in the present study

\begin{tabular}{|c|c|c|c|c|c|c|c|}
\hline \multirow[t]{2}{*}{ Locality } & \multicolumn{2}{|c|}{$\begin{array}{l}\text { Number of } \\
\text { individuals }\end{array}$} & \multicolumn{2}{|l|}{$k$} & \multirow{2}{*}{$\begin{array}{l}\text { Hd } \\
\text { Dloop }\end{array}$} & \multirow{2}{*}{$\begin{array}{l}\text { Gd } \\
S 7\end{array}$} & \multirow[t]{2}{*}{$\begin{array}{l}\text { Collection } \\
\text { date }\end{array}$} \\
\hline & Dloop & $S 7$ & Dloop & $S 7$ & & & \\
\hline \multicolumn{8}{|l|}{ Tripterygion delaisi } \\
\hline Azores & 13 & 10 & 2 & 6 & 0.15 & 0.60 & March 2004 \\
\hline Madeira & 4 & 3 & 1 & 2 & 0.25 & 0.67 & $?$ \\
\hline Canaries & 16 & 13 & 8 & 6 & 0.50 & 0.46 & February 2005 \\
\hline Arrábida, Portugal & 16 & 15 & 1 & 11 & 0.06 & 0.73 & February 2004 \\
\hline Italy (Capri, Vivara) & 12 & 7 & 5 & 5 & 0.42 & 0.71 & June-July 2003 \\
\hline Croatia & 2 & 1 & 2 & 1 & 1 & 1 & $?$ \\
\hline Cyprus & 3 & 1 & 3 & 1 & 1 & 1 & May 2002 \\
\hline Total & 66 & 50 & & & & & \\
\hline \multicolumn{8}{|c|}{ Tripterygion melanurus } \\
\hline Italy (Vivara) & 3 & 3 & & & & & June 2003 \\
\hline \multicolumn{8}{|c|}{ Tripterygion tripteronotus } \\
\hline Spain (Cabo Gata) & 1 & 1 & & & & & July 2004 \\
\hline Italy (Vivara) & 1 & 2 & & & & & June 2003 \\
\hline Greece (Limnos) & 1 & 0 & & & & & July 2003 \\
\hline
\end{tabular}

Number of individuals, number of haplotypes $(k)$, haplotype diversity (Hd) and genotypic diversity (Gd) for mitochondrial control region and $\mathrm{S} 7$ intron are given

Table 2 Fst values for Tripterygion delaisi populations calculated from mitochondrial control region sequences (above the diagonal) and S7 intron (below the diagonal), using ARLEQUIN version 2.000 (Schneider et al. 2000)

\begin{tabular}{|c|c|c|c|c|}
\hline & Azores & Madeira & Canaries & \\
\hline Azores & & $0.085^{+}$ & $0.523^{+*}$ & \\
\hline Madeira & 0.002 & & $0.488^{+}$ & \\
\hline \multirow[t]{2}{*}{ Canaries } & 0.053 & 0.000 & & \\
\hline & Arrábida & Italy & Croatia & Cyprus \\
\hline Arrábida & & $0.606^{+*}$ & $0.981^{+}$ & $0.845^{+}$ \\
\hline Italy & 0.003 & & $0.488^{+}$ & $0.402^{+}$ \\
\hline Croatia & 0.300 & 0.000 & & 0.260 \\
\hline Cyprus & 0.076 & 0.162 & 1.000 & \\
\hline
\end{tabular}

Significant $P$ values $(P<0.05)$ before Bonferroni correction are indicated by + , and after Bonferroni correction are indicated by an asterisk

$\mathrm{SD}=0.008, \min =0.004, \max =0.043$ for $\mathrm{S} 7)$ when compared to the distances within each group (average $=0.008$, $\mathrm{SD}=0.007, \min =0.000, \max =0.036$ for Dloop and average $=0.004, \mathrm{SD}=0.004, \min =0.000 \max =0.018$ for S7 for the eastern Atlantic islands and average $=0.006$, $\mathrm{SD}=0.005, \min =0.000, \max =0.017$ for Dloop and average $=0.009, \mathrm{SD}=0.006, \min =0.027 \max =0.000$ for S7, for Arrábida plus the Mediterranean).

\section{Historical demography}

Historical demography was assessed by determining historical population size and growth using the control region and $\mathrm{S} 7$ intron sequences, for the two groups of populations of Tripterygion delaisi: islands and Arrábida plus Mediterranean (Table 3). The islands group showed a much higher growth rate than the Arrábida plus Mediterranean group for the mitochondrial control region. However, for the S7 intron this relation was the opposite, although the difference between the growth values of the two populations was not as high (Table 3).

Relative historical population size was determined, allowing us to estimate the coalescence time of the two groups of $T$. delaisi. Using the mutation rate $(\mu)$ for mitochondrial control region as $8.24 \times 10^{-8}-$ $9.30 \times 10^{8}$ (Domingues et al. 2005), the islands populations of $T$. delaisi was $1 \%$ of its present size approximately 5,000-6,000 ya (Table 3 ). The coalescence time for Arrábida plus Mediterranean populations was 175,000-210,000 ya. Historical migration between the Atlantic islands and Arrábida plus Mediterranean was restricted, with a trend of migration from the Mediterranean into the Atlantic islands $[22.04( \pm 1.10) / \mu$ Islands immigrants vs. $0.09( \pm 0.27) / \mu$ Mediterranean immigrants; Fig. 1].

\section{Discussion}

The results of this study support the existence of two Tripterygion delaisi clades, one in the eastern Atlantic islands and another in the Atlantic coasts of Europe and in the Mediterranean. All phylogenetic reconstruc- 
Table 3 Demographic parameters of Tripterygion delaisi based on mtDNA control region and S7 intron

$\Theta$ (growth) $g \quad$ Coalescence

time (ya)

Dloop

Islands

$0.005( \pm 0.005)$

$0.016( \pm 0.003)$

Arrábida and Mediterranean

S7

Islands

Arrábida and Mediterranean
$0.033( \pm 0.001)$

$0.052( \pm 0.002)$
$10,000( \pm 0.000)$

$275.12( \pm 8.19)$

$5,000-6,000$

$175,000-210,000$
$59.90( \pm 6.474)$

$369( \pm 20.253)$

Estimates of $\Theta$ (compound parameter representing the effective population size and mutation rate) and $g$ (growth parameter) based on the mitochondrial control region and S7 intron for both groups of T. delaisi (islands and Atlantic plus Mediterranean populations). Coalescence time of $T$. delaisi populations based on mitochondrial control region data is shown in the column 4. Parameters were estimated using FLUCTUATE (Kuhner et al. 1998). The standard deviation is presented between parentheses after each estimator

tion methods partition $T$. delaisi into two major clades (eastern Atlantic islands vs. Arrábida and Mediterranean). High-uncorrected $\mathrm{p}$ distances between these two groups for the mitochondrial control region sequences (0.07) and the S7 intron (0.02), also supports the existence of two highly divergent groups of $T$. delaisi. Indeed, this value is only slightly lower than the distance between each group of $T$. delaisi and the other Tripterygion species: T. tripteronotus $(0.10-0.19$ for Dloop and 0.01-0.04 for S7) and T. melanurus (0.080.12 for Dloop and $0.02-0.06$ for S7). These values are similar to the distance between mitochondrial control region sequences of other blennioid sister species available in the GenBank (Parablennius parvicornis/P. sanguinolentus $=0.13 ; P$. pilicornis $/ P$. salensis $=0.11$; Lipophrys pholis $/$ L. trigloides $=0.17 ;$ L. adriaticus $/ L$. dalmatinus $=0.21$ ).

In addition to the phylogenetic data, gene flow between the eastern Atlantic islands and Arrábida plus Mediterranean was very low (average Fst $=0.94$ and
0.70 for Dloop and S7 intron, respectively). This was also confirmed by the AMOVA analyses showing that the total genetic variance was strongly explained by the existence of two groups of populations of $T$. delaisi (eastern Atlantic islands versus Arrábida and Mediterranean). Moreover, migration between these regions was remarkably restricted.

Several studies have shown restricted gene flow between the Atlantic and the Mediterranean for different marine organisms. Some studies described a strong genetic divergence between Atlantic and Mediterranean faunas, ascribed to the relative isolation of both seas during the Pleistocene glaciations and to present day barriers such as the hydrology in the strait of Gibraltar. Genetic discontinuities between the Atlantic and the Mediterranean were found for four sparids (Bargelloni et al. 2003, 2005), for the cuttlefish Sepia officinalis (Pérez-Losada et al. 1999, 2002) and the mussel Mytilus galloprovincialis (Quesada et al. 1995). Other species such as the ornate wrasse (Thalassoma pavo,
Fig. 1 Tripterygion delaisi sampling locations. $T$. delaisi samples were collected in the northeastern Atlantic islands, Portuguese Atlantic coast, and in the Mediterranean. Labels are Azores $(A z o)$, Madeira $(M a d)$, Canaries (Can), Arrábida (Arr), Italy (Ita), Croatia (Cro), and Cyprus $(C y p)$. The extend of migration between the two clades of T. delaisi are indicated in the figure. Number of migrants scaled by the mutation rate were estimated using MIGRATE 2.0 (Beerli 2004 )

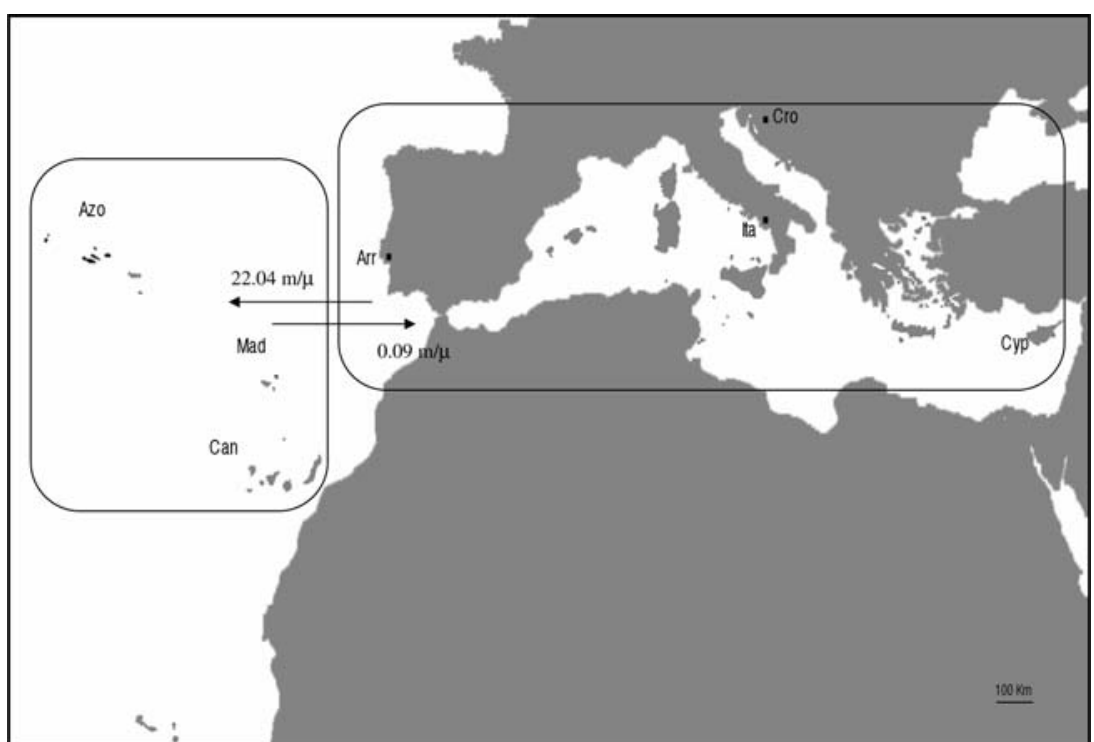




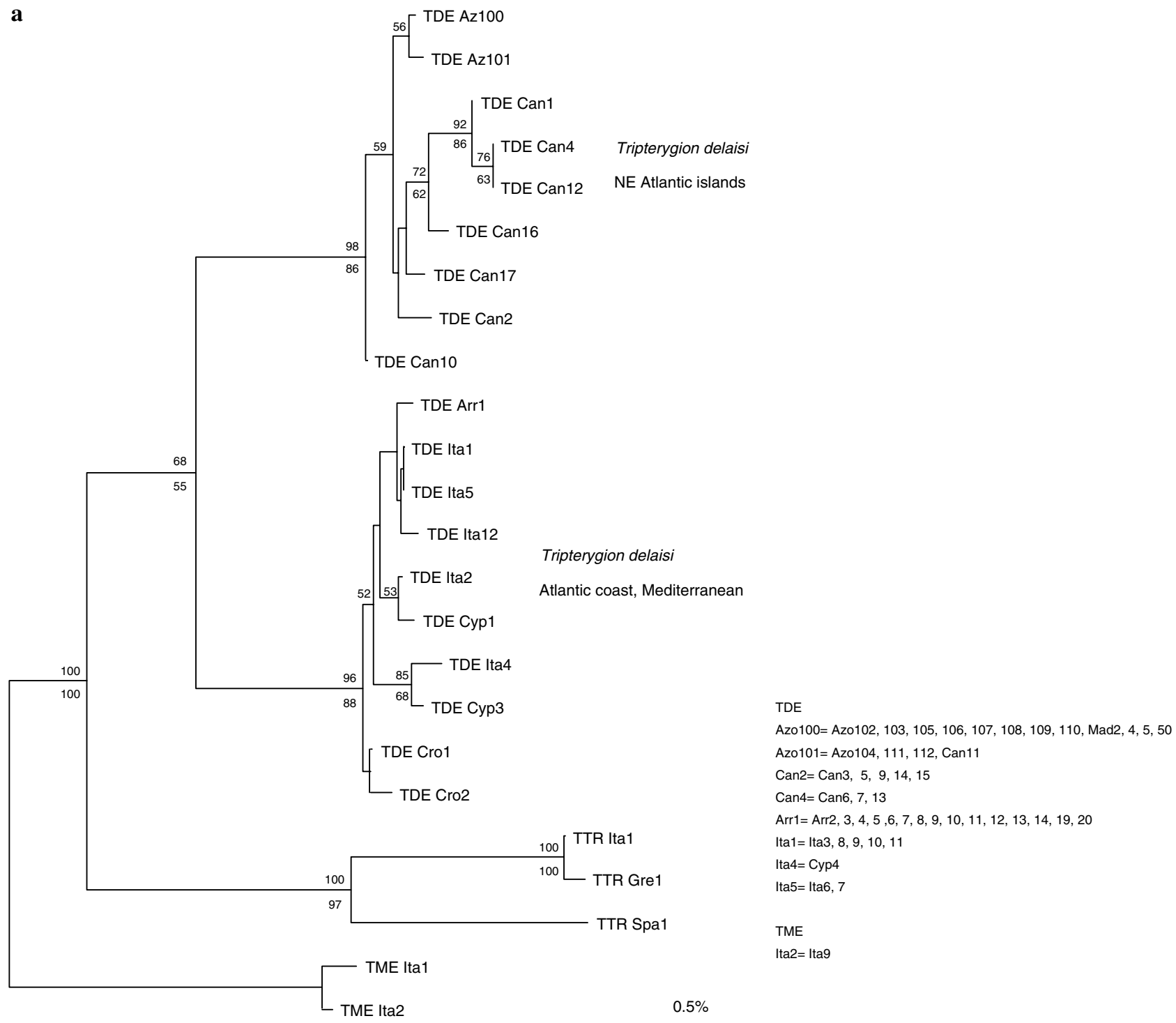

Fig. 2 Phylogenetic relationship within Tripterygion delaisi for the mitochondrial control region sequences (a) and S7 intron (b). $T$. tripteronotus and T. melanurus were also included and T. melanuros was used as outgroup., Neighbor-joining trees are shown with neighbor-joining (above the nodes) and maximum parsimony (below the nodes) bootstrap support above $50 \%$ indicated at the nodes. Labels are T. delaisi (TDE), T. tripteronotus (TTR), T. melanuros (TME), Azores (Azo), Madeira (Mad), Canaries (Can), Arrábida (Arr), Spain (Spa), Italy (Ita), Croatia (Cro), Greece (Gre), and Cyprus (Cyp). The length of each branch is proportional to the number of nucleotide substitutions. Scale bar: $0.5 \%$ Uncorrected $P$ distance
Costagliola et al. 2004), the chub mackerel (Scomber japonicus, Zardoya et al. 2004), the withe sea-bream (Diplodus sargus, Bargelloni et al. 2005) and the Norway lobster (Nephrops norvegicus, Stamatis et al. 2004) were described as having high gene flow levels between the Atlantic and the Mediterranean and no signs of an Atlantic-Mediterranean divide. These contrasting patterns may stem from different biological characteristics of the species. Larval ecology in particular, is well known to affect the extent of gene flow (eg. Riginos and Victor 2001). Results for T. delaisi are contradic- tory. Fst values between Arrábida and Italy (the most western location of the Mediterranean in our study) are high for the mitochondrial control region but very low for the S7 intron (0.606 and 0.003, respectively, Table 2). All individuals from Arrábida are represented by a single mitochondrial control region haplotype, which is not present in any of the other populations. However, the uncorrected $\mathrm{p}$ distances between Arrábida and Italy are very small (0.005), indicating that the haplotype of Arrábida is similar to Italy's. 


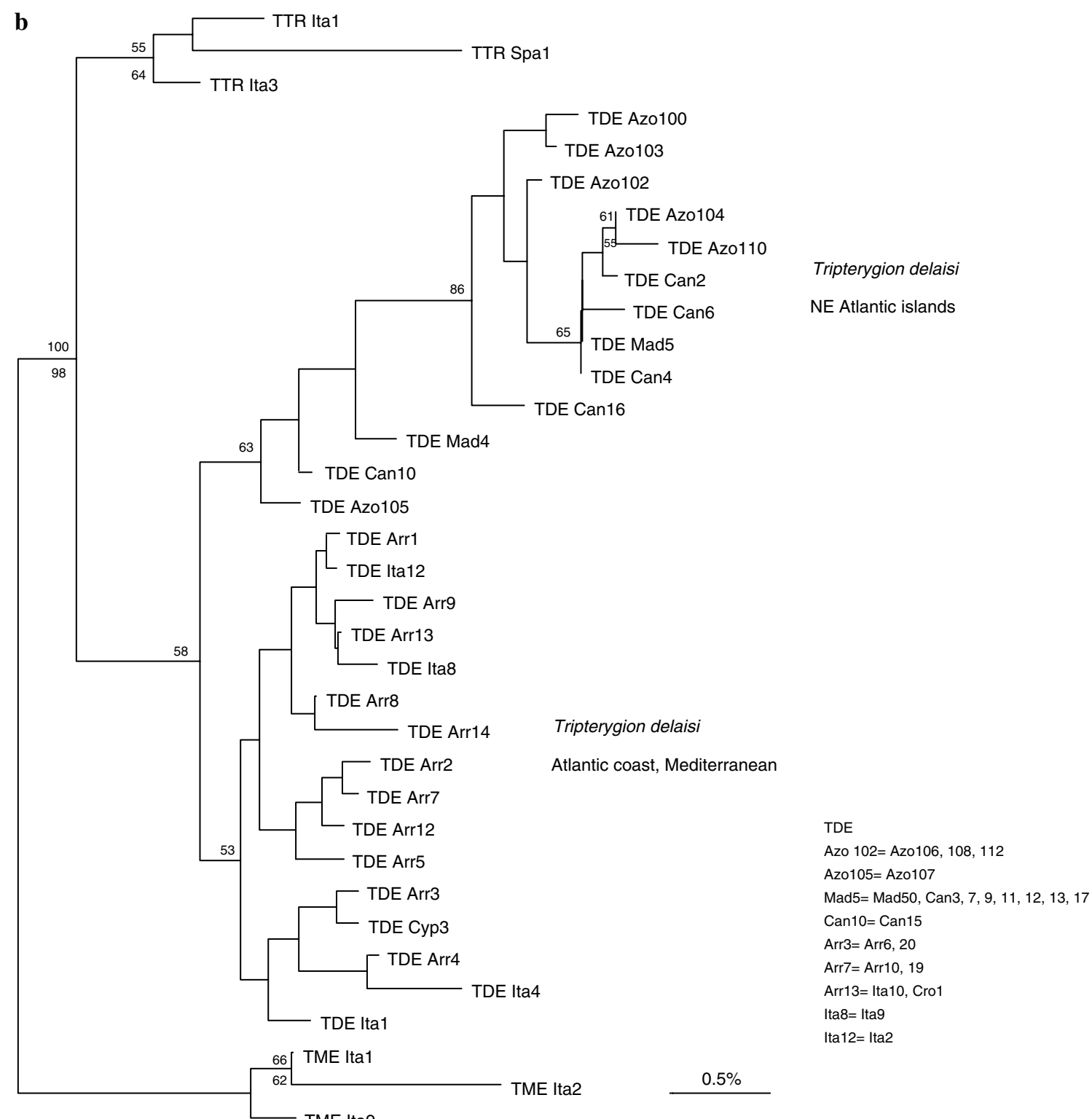

Fig. 2 continued

Zander (1986) described Atlantic and Mediterranean subspecies of $T$. delaisi. However, both phylogenetic and population analysis in this study showed that the individuals from the Atlantic coast of Portugal, like the one from norwestern Spain included in CarreralCarbonell et al. (2005), are more closely related to the Mediterranean fish than to those from the Atlantic islands. This biogeographic pattern is also seen in other sister species such as the blennids Parablennius parvicornis/P. sanguinolentus (Almada et al. 2005a), and the pomacentrids Chromis limbata/C. chromis (Domingues et al. 2005). In these cases, one of the species is restricted to the Macaronesian islands and the Atlantic tropical coast of Africa, while the other is found in the Mediterranean and Atlantic coast of southwest Europe. In the blenniids, a family closely related to the tripterygids, Almada et al. (2005b) showed that at least two clades (Macrolipophrys and Parablennius) have species in Tropical Africa that have counterparts in the Mediterranean and adjacent Atlantic waters. The examples cited above and the distribution of the two $T$. delaisi clades point to the conclusion that, in many instances, the main split is not between coastal Atlantic and Mediterranean populations. Instead, many clades split in two groups: one comprising populations from western Africa, and often the Macaronesian islands, 
and another including the Mediterranean plus a more or less extensive range of the northeastern Iberian Atlantic.

The times of coalescence of the eastern Atlantic islands population and the Mediterranean plus Arrábida population of $T$. delaisi were more recent than the onset of Pleistocene glaciations, which occurred, 1.7 Mya (Briggs 1996) (Table 3). This result shows a more recent separation of the two $T$. delaisi clades than what was suggested by Carreras-Carbonell et al. (2005). These authors estimated the evolutionary rate for 12SrDNA and 16SrDNA mitochondrial genes assuming that the speciation process of Tripterygion started when the Strait of Gibraltar reopened. Using this calibration they found that the two clades of $T$. delaisi were separated $1.23 \pm 0.45$ and $1.10 \pm 0.49$ Mya for $12 \mathrm{~S}$ and $16 \mathrm{~S}$, respectively. Using the $12 \mathrm{~S}$ genetic distances from Carreras-Carbonell et al. (2005), and applying an internally calibrated molecular clock based on the closely related blenniid geminate transisthmian pair Ophioblennius atlanticus and O. steindachneri (sequences available at GenBank), we estimated the time of separation of the two $T$. delaisi clades at $0.64 \pm 0.23$ Mya. This result is more in agreement with our coalescence time estimation, specially taking into account that the divergence time of two sister species has been shown to most likely be an overestimate of their actual coalescence time (Edwards and Beerli 2000).

The biogeographical hypothesis proposed by Zander (1980), considered the eastern Atlantic islands, especially the Azores, as speciation centers that exported colonizers to the Mediterranean and adjacent Atlantic coast. This hypothesis predicts an older coalescence time of the islands population in relation to the Mediterranean and adjacent Atlantic coasts. The present results, however, do not support this prediction as the islands population showed a more recent origin than the Arrábida plus Mediterranean populations for the mitochondrial control region sequences (Table 3). Moreover, although migration between the islands and Arrábida plus Mediterranean was restricted, it showed a westbound trend, with a higher number of migrants going from the Arrábida plus Mediterranean into the islands $[22.04( \pm 1.10) / \mu]$ than the opposite $[0.09$ $( \pm 0.27) / \mu$; Fig. 1$]$.

Our results, are consistent with the hypotheses of Wirtz $(1978,1980)$ and Almada et al. (2001), that consider successive dispersal events from the western African coast which could follow two routes: (a) one that would successively colonize the Atlantic islands; (b) another directed northwards, along the continental coast of Africa, that would colonize the Mediterra- nean. The southern Mediterranean would act as a refugium during glacial periods and as a secondary speciation center for warm water species, which would colonize the Atlantic shores of the Iberian Peninsula (and in some cases the western European shores more to the north), and northwestern Africa, during interglacial periods like the present one (Almada et al. 2001). Indeed, during some glacial maxima (e.g. 18,000 years ago) the polar front, with water temperatures of $4^{\circ} \mathrm{C}$, moved as far south as $37^{\circ} \mathrm{N}$ (Dias et al. 1997). These extremes of low temperature must have eliminated all tropical, subtropical, and warm temperate fauna along the shores of southwestern Europe and northwestern Africa. Thus, T. delaisi Arrábida population might have been the result of a post-glacial colonization from the Mediterranean. The low genetic diversity of this population shown for the mitochondrial control region supports this hypothesis.

This scenario is also in agreement with the speciation processes proposed by Jonge and Videler (1989) and Geertjes et al. (2001) for the other Mediterranean triplefins. These authors consider different processes of speciation, all occurring within the Mediterranean, which has acted as a refugium during the Pleistocene glaciations.

Our hypothesis is reinforced by the lack of records of Tripterygion in the African Atlantic coast from Casablanca south to Senegal (Brownell 1978). Recent studies of coastal fishes in the Sahara coast have not recorded specimens of this triplefin blennioid (Falcón et al. 2002). It is likely that the situation is similar to that of the sister species Parablenius parvicornis and $P$. sanguinolentus. P. parvicornis occurs in tropical Africa and the Macaronesian islands while $P$. sanguinolentus are restricted to the Mediterranean and adjacent north Atlantic waters (Almada et al. 2005a). This species pair is also absent from the western African coast north of Cape Blanco (Mauritania). It seems that the African upwelling has played an important role as a biogeographical barrier for littoral species, promoting the divergence of the tropical populations and those of the Mediterranean and adjacent Atlantic.

The presence of $T$. delaisi in the Macaronesian islands could be related to the larval transport from the African coast by water filaments that reach the Canaries (Barton et al. 1998; Rodríguez et al. 1999), or to the maintenance of the populations in the warmer zones of the islands (Madeira or the westernmost Canary Islands) during the last glacial period, as it seems to have occurred in other cases (Miller 1984). The complex eddies system of the Canary Current may have allowed a northwards dispersal to the Azores (Stramma 1984; Santos et al. 1995). 
In this study, we show the existence of two highly divergent clades of Tripterygion delaisi, that correspond to the two clades identified by Carrera-Carbonell et al. (2005). Are these two clades equivalent to the two subspecies Tripterygion delaisi xanthosoma and $T$. $d$. delaisi defined by Zander and Heymer (1970)? With molecular data only, this question cannot be adequately answered. Detailed morphological, behavioral, biogeographical and genetic work encompassing the entire distribution area of what is now called $T$. delaisi is urgently needed to address this issue. The study of specimens from Senegal is particularly important in this respect.

Acknowledgments We would like to thank P. Wirtz and R. Hanel for Triprerygion samples from different localities. We also thank P. Wirtz for his helpful comments. This research was partly founded by a PhD grant SFRH/BD/13069/2003, from the Portuguese Foundation for Science and Technology (VSD), and by the David and Lucille Packard Foundation's PISCO program. ISPA and IMAR-DOP/UAz are funded by FCT through a pluri-annual and programmatic funding schemes (FEDER).

\section{References}

Almada VC, Oliveira RF, Gonçalves EJ, Almeida AJ, Santos RS, Wirtz P (2001) Patterns of diversity of the north-eastern Atlantic blenniid fish fauna (Pisces:Blenniidae). Glob Ecol Biogeogr 10:411-422

Almada F, Almada VC, Domingues VS, Brito A, Santos RS (2005a) Molecular validation of the specific status of Parablennius sanguinolentus and Parablennius parvicornis ( $\mathrm{Pi}-$ sces: Blenniidae). Sci Mar 69(4):519-523

Almada F, Almada VC, Guillemaud T, Wirtz P (2005b) Phylogenetic relationships of the north-eastern Atlantic and Mediterranean blenniids. Biol J Linn Soc 86:283-295

Aurelle D, Guillemaud T, Afonso P, Morato T, Wirtz P, Santos RS, Cancela ML (2003) Genetic study of Coris julis (Osteichtyes, Perciformes, Labridae) evolutionary history and dispersal abilities. C R Biol 326:771-785

Bargelloni L, Alarcorn JA, Alvarez MC, Penzo E, Magoulas A, Reis C, Patarnello T (2003) Discord in the family Sparidae (Teleostei): divergent phylogeographical patterns across the Atlantic-Mediterranean divide. J Evol Biol 16:1149-1158

Bargelloni L, Alarcon JA, Alvarez MC, Penzo E, Magoulas A, Palma J, Patarnello T (2005) The Atlantic-Mediterranean transition: discordant genetic patterns in two seabream species, Diplodus puntazzo (Cetti) and Diplodus sargus (L.). Mol Phyl Evol 36:523-535

Barton ED, Arístegui J, Tett P, Cantón M, García-Braun J, Hernández-León S, Nykjaer L, Almeida C, Almunia J, Ballesteros S, Basterretxea G, Escánez J, García-Weill L, HernándezGuerra A., López-Laatzen F, Molina R, Montero MF, Navarro-Pérez E, Rodríguez J M, Lenning K van, Vélez H, Wild K (1998) The transition zone of the Canary Current upwelling region. Prog Oceanogr 41:455-504

Beerli P (2004) Migrate: documentation and program, part of Lamark. Version 2.0. Available at http://evolution.gs.washington.edu/lamarc.html

Beerli P, Felsenstein J (2001) Maximum likelihood estimation of a migration matrix and effective population sizes in $n$ sub- populations by using a coalescent approach. Proc Natl Acad Sci USA 98:4563-4568

Borsa P, Blanquer A, Berrebi P (1997) Genetic structure of the flounders Platichthys flesus and P. Stellatus at different geographic scales. Mar Biol 129:233-246

Briggs JC (1974) Marine Zoogeography. Mcgraw-Hill, London

Briggs JC (1996) Global Biogeography Vol. 14. Developments in Paleontology and Stratigraphy. Elsevier, Amsterdam

Brownell CL (1978) Sur quelques collections de poissons littoraux de l'Atlantique Marocain. Bull Inst Pêches Marit 23:111-133

Carreras-Carbonlell J, MacPherson E, Pascual M (2005) Rapid radiation and cryptic speciation in mediterranean tripleWn blennies (Pisces: Tripterygiidae) combining multiple genes. Mol Phyl Evol 37:751-761

Chikhi L, Agnese JF, Bonhomme F (1997) Strong differences of mitochondrial DNA between Mediterranean Sea and eastern Atlantic populations of Sardinella aurita. Comptes Rendus de l' Academie des Sciences Serie III Sci Vie 320:289_ 297

Chow S, Hazama K (1998). Universal PCR primers for S7 ribosomal protein gene introns in fish. Mol Ecol 7:1247-1263

Costagliola D, Robertson DR, Guidetti P, Stefanni S, Wirtz P, Heiser JB, Bernardi G (2004) Evolution of coral reef fish Thalassoma pavo spp. (Labridae). 2. Evolution of the eastern Atlantic species. Mar Biol 144:377-383

Dias JA, Rodrigues A, Magalhães F (1997) Evolução da linha de costa em Portugal, desde o último máximo glaciário até à actualidade: síntese dos conhecimentos. Estudos do Quaternário 1:53-66

Domingues VS, Bucciarelli G, Almada VC, Bernardi G (2005) Historical colonization and demography of the Mediterranean damselfish, Chromis chromis. Mol Ecol 14:40514063

Duran S, Pascual M, Turon X (2004) Low levels of genetic variation in mtDNA sequences over the western Mediterranean and Atlantic range of the sponge Crambe crambe (Poecilosclerida). Mar Biol 144:31-35

Edwards SV, Beerli P (2000) Gene divergence, population divergence, and the variance in coalescence time in phylogeographic studies. Evolution 54:1839-1854

Excoffier L, Smouse PE, Quattro JM (1997) Analysis of molecular variance inferred from metric distances among DNA haplotypes: application to human mitochondrial DNA restriction data. Genetics 131:479-491

Falcón JM, Brito A, González G (2002) Peces de la laguna de Khnifiss (Sáhara, NW África) y de los sectores costeros próximos. Re Acad Canar Cienc 14(3-4):139-152

Felsenstein J (1985) Confidence limits on phylogenies: an approach using the bootstrap. Evolution 39:783-791

Geertjes GJ, Kamping A,van Delden W, Videler JJ (2001) Genetic relationships among one non-endemic and two endemic mediterranen Triplefin Blennies (Pisces, Blennioidei). Mar Ecol 22:255-265

Jonge J, Videler JJ (1989) Differences between the reproductive biologies of Tripterygion tripteronotus and T. delaisi (Pisces, Perciformes, Tripterygiidae) the adaptive significance of an alternative mating strategy and a red instead of a yellow nuptial colour. Mar Biol 100:431-437

Kotoulas G, Magoulas A, Tsimenides N, Zurros E (1995) Marked mitochondrial differences between Mediterranean and Atlantic populations of the swordfish Xiphias gladius. Mol Ecol 4:473-481

Kuhner MK, Yamato J, Felsenstein J (1998) Maximum likelihood estimation of population growth rates based on the coalescent. Genetics 149:429-434 
Lee WJ, Conroy J, Howell WH, Kocher TD (1995) Structure and evolution of teleost mitochondrial control regions. J Mol Evol 41:54-66

Miller PJ (1984) The gobiid fishes of temperate Macaronesia (eastern Atlantic). J Zool Lond 204:363-412

Naciri M, Lemaire C, Borsa P, Bonhomme F (1999) Genetic study of the Atlantic/Mediterranean transition in Sea bass (Dicentrarchus labrax). J Hered 90:591-596

Nei M, Kumar S (2000) Molecular Evolution and Phylogenetics. Oxford University Press, Oxford

Pérez-Losada M, Guerra A, Sanjuan A (1999) Allozyme differentiation in the cuttlefish Sepia officinalis (Mollusca: Cephalopoda) from the NE Atlantic and Mediterranean. Heredity 83:280-289

Pérez-Losada M, Guerra A, Carvalho GR, Sanjuan A, Shaw PW (2002) Extensive population subdivision of the cuttlefish $\mathrm{Se}$ pia officialis (Mollusca: Cephalopoda) around the Iberian Peninsula indicated by microsatellite DNA variation. Heredity 89:417-424

Quesada H, Beynon CM, Skibinski DOF (1995) A mitochondrial DNA discontinuity in the mussel Mytilus galloprovincialis Lmk: Pleistocene vicariance biogeography and secondary intergradation. Mol Biol Evol 12:521-524

Raventós N, Macpherson E (2001) Planktonic larval duration and settlement marks on the otoliths of Mediterranean littoral fishes. Mar Biol 138:1115-1120

Rice WR (1989) Analyzing tables of statistical tests. Evolution 43:223-225

Riginos C, Victor BC (2001) Larval spatial distributions and other early life-history characteristics predict genetic differentiation in eastern Pacific blennioid fishes. Proc R Soc Lond B 268:1931-1936

Rodríguez JM, Hernández-León S, Barton ED (1999) Mesoscale distribution of fish larvae in relation to an upwelling filament off Northwest Africa. Deep-Sea Res I 46:1969-1984

Sambrook J, Fritsch EF, Maniatis T (1989) Molecular Cloning a Laboratory Manual. 2nd edn. Cold Spring Harbor Laboratory Press, New York

Santos RS, Hawkins S, Monteiro LR, Alves M, Isidro EJ (1995) Marine research, resources and conservation in the Azores. Aquat Conserv Mar Freshw Ecosyst 5:311-354
Schneider S, Roessli D, Excoffier L (2000) ARLEQUIN, Version 2.000: A Software for Population Genetics Data Analysis. University of Geneva, Switzerland

Stamatis C, Trianfylidis A, Moutou KA, Mamuris Z (2004) Mitochondrial DNA variation in Northeast Atlantic and Mediterranean populations of Norway lobster, Nephrops norvegicus. Mol Ecol 13:1377-1390

Stramma L (1984) Geostrophic transport in the warm water sphere of the eastern subtropical North Atlantic. J Mar Res 42:537-558

Swofford DL (1998) PAUP: phylogenetic analysis using parsimony and other methods. Sinauer Associates, Sunderland

Wares JP, Cunningham CW (2001) Phylogeography and historical ecology of the north Atlantic intertidal. Evolution 55:2455-2469

Wirtz P (1978) The behaviour of the Mediterranean Tripterygion species (Pisces, Blennioidei). Zeit Tierpsychol 48:142-174

Wirtz P (1980) A revision of the eastern Atlantic Tripterygiidae (Pisces, Blennioidei) and notes on some westafrican blennioid fish. Cybium 11:83-101

Wirtz P (1990) Tripterygiidae. In: Quero JC, Hureau JC, Karrer C, Post A, Saldanha A (eds) Check-list of the fishes of the eastern tropical Atlantic (CLOFETA). UNESCO, Paris, pp 916-917

Zander CD (1973) Evolution of blennioidei in the Mediterranean sea. Rev Trav Inst Pêches Marit 37:215-221

Zander CD (1980) Zoogeography and speciation of Mediterranean blennioids. Journées de Etudes Systématiques et Biogéographiques de Mediterraneen, CIESM, Cagliari,13-38

Zander CD (1986) Blenniidae. In: Whitehead PM, Bauchot L, Hureau, Nielsen $\mathbf{J}$ and Tortonese $E$ (eds) Fishes of the North-Eastern Atlantic and the Mediterranean. Vol. 3, UNESCO, Paris, pp 1096-1112

Zander CD, Heymer A (1970) Tripterygion tripteronotus (Risso, 1810) und Tripterygion xaenthosoma n. sp. Eine Okologische Speziation (Pisces, Teleostei). Vie Milieu 21:363-394

Zardoya R, Castilho R, Grande C, Favre-Krey L, Caetano S, Marcato S, Krey G, Patarnello T. (2004) Differential population structuring of two closely related fish species, the mackerel (Scomber scombrus) and the chub mackerel (Scomber japonicus), in the Mediterranean Sea. Mol Ecol 13:1785-1798 